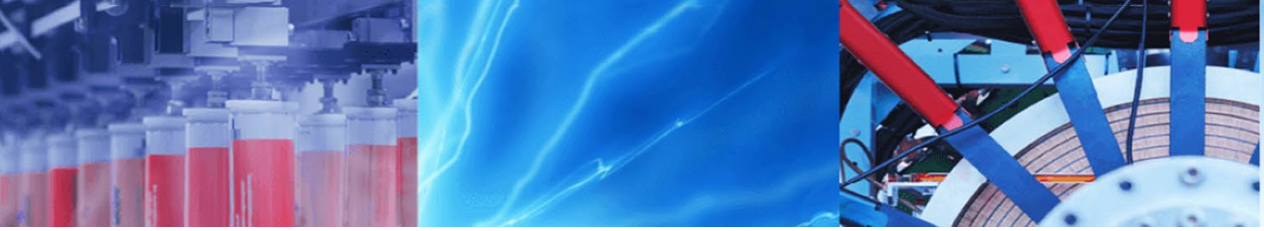

Research Article

\title{
Synthesis of $\mathrm{a}-\mathrm{Al}_{2} \mathrm{O}_{3}-$ graphene composite: a novel product to provide multi-functionalities on steel strip surface
}

\author{
Tapan Dash ${ }^{1} \cdot$ Tapan Kumar Rout ${ }^{2} \cdot$ Binod Bihari Palei $^{3} \cdot$ Shubhra Bajpai $^{3} \cdot$ Saurabh Kundu $^{2} \cdot$ Amar N. Bhagat $^{2}$. \\ Bijoy Kumar Satpathy ${ }^{4} \cdot$ Susanta Kumar Biswal ${ }^{1} \cdot$ Abhinay Rajput $^{3}$ - Ashok Kumar Sahu ${ }^{3}$. Surendra Kumar Biswal ${ }^{3}$
}

Received: 21 September 2019 / Accepted: 2 April 2020 / Published online: 1 June 2020

(c) Springer Nature Switzerland AG 2020

\begin{abstract}
We successfully prepare a composite retaining crystalline structure of $\mathrm{a}-\mathrm{Al}_{2} \mathrm{O}_{3}$ and graphene using a dry (no chemical) planetary ball milling technique. The composite was then coated efficiently on steel substrate via a non-transferred plasma torch. Good adhesion with almost uniform microstructural distribution of a- $\mathrm{Al}_{2} \mathrm{O}_{3}-$ graphene composite (4 wt\%) on steel substrate was shown in FESEM study. It was remarkably observed that $\mathrm{a}-\mathrm{Al}_{2} \mathrm{O}_{3}$-graphene (4 wt\%) composite coated on steel substrate improves its surface properties exhibiting hardness and Young's modulus of $370 \pm 11 \mathrm{VHN}$ and $292 \pm 22 \mathrm{GPa}$, respectively. This sample is also found to show significant high electrical conductivity of $\sim 6.6 \times 10^{6} \mathrm{~S} / \mathrm{m}$. This composite can be an alternate coating to hard chrome coating, carburisation and nitriding with added advantage of surface conductivity.
\end{abstract}

Keywords Powder processing $\cdot$ Composites $\cdot$ Alumina $\cdot$ Graphene $\cdot$ Coating

\section{Introduction}

Steel has been widely used for both domestic and industrial application owing to its excellent mechanical properties. The weaknesses of steel are corrosion, low surface hardness in comparison to hard ceramics \& refractories and poor wear resistance behaviours [1-5]. To meet these disadvantages, many protection methods are being continuously developed to improve service life of steel against corrosion, load and wear attacks [5-7] in every critical applications. Over the years, researchers have developed different surface alloying methods, different surface hardening methods, different composition and/or post-preparation treatments such as coating to improve the properties of steel surface [8-10]. We found from literature that thin film coatings and overlays generally become less cost effective as production quantities increase, especially when the entire surface of work pieces needs to be hardened by good quality coating with appropriate choice of materials. It is reported that coating is an alternative method against surface alloying that can be used to develop the quality of steel, which would allow steel to be used during critical conditions of mechanical, thermal and/or corrosion resistance for longer duration of time [8-10]. One can be able to do smart coating with unique combination of electrical, mechanical and thermal properties of graphene [11-18], it is believed that it could be used to enhance the performance of coating of metals, polymers and ceramics significantly. In particular, with superior mechanical properties (strength $\sim 130 \mathrm{GPa}$, Young modulus $\sim 1 \mathrm{TPa}$ ) of graphene, its sheets and nanoplatelets serve as excellent strengthening inclusions in metal-matrix with ceramic composites [11-18]. Electrodeposited graphene oxide

Tapan Dash, tapan.dash@cutm.ac.in | ${ }^{1}$ Centurion University of Technology and Management, Bhubaneswar, Odisha, India. ${ }^{2}$ Research \& Development Department, Tata Steel Ltd, Jamshedpur, Odisha, India. ${ }^{3}$ CSIR-Institute of Minerals and Materials Technology, Bhubaneswar, Odisha, India. ${ }^{4}$ IIT-Bhubaneswar, Bhubaneswar, Odisha, India. 
coating and graphene composites have been reported to improve the corrosion resistance of steel $[19,20]$ but the corrosion protection of metal using graphene derivative alone is a problem due to its weak adhesion on metal surfaces. $\mathrm{Ni} / \mathrm{GO}-\mathrm{Al}_{2} \mathrm{O}_{3}$ coatings on steel with mass ratio of $\mathrm{GO}$ and $\mathrm{Al}_{2} \mathrm{O}_{3}$ of $1: 1$ prepared by electro-deposition method show microhardness of $500 \mathrm{HV}$ [21]. It is also reported that graphene 2.35 vol\% of doped $\mathrm{Al}_{2} \mathrm{O}_{3}$ composites show electrical conductivity of $1000 \mathrm{~S} / \mathrm{m}$ [22]. Literature shows that the Young's modulus of steel coated with $\mathrm{Al}_{2} \mathrm{O}_{3}$ and CNT decreases upon the increase in carbon content, from $41 \mathrm{GPa}$ for $\mathrm{Al}_{2} \mathrm{O}_{3}$ to $9 \mathrm{GPa}$ containing $25 \%$ C [23]. From 0 to 14 wt.\% of carbon, the hardness is found to be constant $(\sim 1000 \mathrm{MPa})$ which then shows a decreasing trend and reaches only $200 \mathrm{MPa}$ for steel coated with $\mathrm{Al}_{2} \mathrm{O}_{3}$ and CNT, having 25\% C [23]. However, there is still limited studies in literature regarding the use of coating techniques for enhancement of electrical conductivity as well as surface hardness property of common steel by using the graphene derivatives along with ceramics like $\mathrm{Al}_{2} \mathrm{O}_{3}$. $\mathrm{Al}_{2} \mathrm{O}_{3}$ essentially its a-phase is one of the highly used structural ceramics in the materials industry and found to be used in high-speed cutting tools, chemical and electrical insulators, wear resistance parts and various coatings, due to its high hardness, chemical inertness, very good adhesive property on metals and high electrical and thermal insulating properties [24-27]. It may be thought that by exploring the properties of $\mathrm{Al}_{2} \mathrm{O}_{3}$ and graphene, a fascinating and protecting material can be designed for advanced industrial coating applications, particularly for high hardness, high electrical conductivity along with anti-corrosion type of applications.

In this work, it has been possible to prepare $\mathrm{a}-\mathrm{Al}_{2} \mathrm{O}_{3}$-graphene composites $(1,2 \& 4 \mathrm{wt} \%)$ by $12 \mathrm{~h}$ of dry planetary balling milling technique. The paper demonstrates successful coating of $\mathrm{a}-\mathrm{Al}_{2} \mathrm{O}_{3}$ and $\mathrm{a}-\mathrm{Al}_{2} \mathrm{O}_{3}$-graphene composites on steel substrate by employing less energy-intensive non-transferred plasma torch technique. The microstructural, spectroscopic, mechanical and electrical properties of steel with coating of $\mathrm{a}-\mathrm{Al}_{2} \mathrm{O}_{3}$ and $\mathrm{a}-\mathrm{Al}_{2} \mathrm{O}_{3}-$ graphene composites were investigated by employing various techniques such as $\mathrm{X}$-ray diffraction (XRD), field emission scanning electron microscopy (FESEM), micro-Raman spectroscopy, microhardness and Young's modulus by nanoindentation and electrical conductivity measurement. XRD and micro-Raman analysis confirm the preparation and coating of $a-\mathrm{Al}_{2} \mathrm{O}_{3}$-graphene composite on steel substrate. It was also observed that coating of $\mathrm{a}-\mathrm{Al}_{2} \mathrm{O}_{3}$-graphene improves mechanical and electrical properties of steel. To the best of our knowledge, this is possibly the first report on such novel material prepared by non-transferred plasma torch technique.

\section{Materials and methods}

\subsection{Synthesis of composite by ball milling route}

At first graphene was prepared from high-purity graphite (particle size of graphite 150 micron) by using horizontal high-energy dry planetary ball milling technique under hydrogen atmosphere. The ball milling was carried out for $12 \mathrm{~h}$. In the planetary ball mill, the sample-to-ball charge ratio of 1:7 was maintained. The planetary ball mill was designed in such a way that it generates both impact and shear forces to the samples. The planetary ball mill works in order to overcome the limitation of the gravitational field and continuously supply strong acceleration field. The planetary ball mill has basic component of a gyratory shaft $(580 \mathrm{~mm})$ and two cylindrical steel jars of diameter $200 \mathrm{~mm}$ each, both are rotated simultaneously and separately at a speed of $345 \mathrm{rpm}$ and $160 \mathrm{rpm}$, respectively. The rotational dynamics of both jars and the shaft support the balls (inside the chamber) to move very strongly and violently, leading to large impact energy of balls which improves the grinding kinetics and prepares ultrafine composites of nanometric range. After the successful synthesis of graphene, the three different mixture compositions of a- $-\mathrm{Al}_{2} \mathrm{O}_{3}$-graphene were prepared by varying wt $\%$ of graphene i.e. $1,2,4 \%$ in the matrix of $\mathrm{Al}_{2} \mathrm{O}_{3}$. The ball milling of samples with different ratios of $\mathrm{a}-\mathrm{Al}_{2} \mathrm{O}_{3}$-graphene were carried for $12 \mathrm{~h}$ under hydrogen atmosphere. After the successful preparation of powder, samples are taken for coating on steel by employing a non-transferred plasma torch.

\subsection{Coating on steel by employing a non-transferred plasma torch}

Three steel substrates were coated with alumina $\left(a-\mathrm{Al}_{2} \mathrm{O}_{3}\right)$ and alumina-graphene composite powder. Typical chemical composition of steel is C 0.096, Si 0.18; Mn 1.54; P 0.011, $\mathrm{S} 0.005, \mathrm{Cr} 0.22, \mathrm{Ni}<0.002$, Mo 0.003 and Al 0.39. An APS plasma system (Metallisation) consisting of PS50M plasma gun installed at Advance Material Department of CSIRIMMT, Bhubaneswar, Odisha, India is used to spray a- $\mathrm{Al}_{2} \mathrm{O}_{3}$ and $\mathrm{a}-\mathrm{Al}_{2} \mathrm{O}_{3}$-graphene coating on steel substrate at a energy level of $25 \mathrm{KWh}$. Before coating experiments were carried out on steel, blasting was done by $\mathrm{Al}_{2} \mathrm{O}_{3}$ grit on the surface of steel substrates to achieve $\approx 12 \mu \mathrm{m}$ for better adhesive strength. Then bond coat of NiCrAlY was applied on the substrate surface to reduce the thermal expansion mismatch between steel substrate and alumina-graphene composite coating.

In this work, in the atmospheric plasma spray process, plasma gas is formed by burning of electric arc between 
the cathode and anode inside the burner. Mixture of argon ( $\mathrm{Ar}$ ) and hydrogen $\left(\mathrm{H}_{2}\right)$ is used as the plasmagen gas. The role of carrier gas is to carry the powder particles to the nozzle injection. The flow rate of the carrier gas was maintained constant at 2.5 litres per minute (LPM). After the injection of powder particles into the torch, they entered the molten state and the deposition of the molten/semi-molten powder on the mild steel substrate $(4 \mathrm{~cm} \times 4 \mathrm{~cm} \times 1 \mathrm{~cm})$ was carried out. Substrate was kept in the substrate holder at a distance of $120 \mathrm{~mm}$ from the plasma gun. Preheating of substrate was carried out at a temperature of $110^{\circ} \mathrm{C}$ by using plasma torch. To and fro motion of the plasma torch was done with the help of a six-axis robot to obtain the required coating thickness. After the coating process, the coated products wee left for rapid solidification process with a cooling rate of approximately $110 \mathrm{~K} / \mathrm{s}$. The coated samples of steel were taken for evaluating the properties by employing various techniques.

\subsection{Characterization techniques used for evaluating the properties of materials}

XRD patterns of the steel coated with $\mathrm{a}-\mathrm{Al}_{2} \mathrm{O}_{3}$ and $\mathrm{a}-\mathrm{Al}_{2} \mathrm{O}_{3}$ - graphene samples were carried out by PANalytical X'Pert Pro diffractometer equipped with CoKa radiation. The patterns were taken in the $2 \theta$ range of 5-95 at a scan speed of $0.017 \mathrm{~min}^{-1}$. Micro-Raman spectra were recorded by employing a dispersive-type Renishaw invia Reflex (UK) spectrometer with a spectral resolution of $1 \mathrm{~cm}^{-1}(514 \mathrm{~nm}$ line of an $\mathrm{Ar}+$ ion laser). The microstructures of samples were observed by FESEM (model: ZEISS SUPRA 55). Energy dispersive spectra (EDS) study of the composites was taken using the Oxford, X-Max system. The constituents of different phases grown in the sample were confirmed by EDS analysis. Typical nanoindentation of the samples was determined by nanoindenter-UMIS system (Fisher-Cripps, Australia) with diamond Berkovich indenter (tip diameter: $400 \mathrm{~nm}$ ) at a maximum applied load of $50 \mathrm{mN}$. Pure steel, a- $-\mathrm{Al}_{2} \mathrm{O}_{3}$ and typical a- $\mathrm{Al}_{2} \mathrm{O}_{3}$-graphene (4 wt\%) composite coated on steel substrate were used for electrical resistivity/conductivity (dc) measurement by four-point probe method. Four numbers of very fine $\mathrm{W}$ wire probe were mounted on the central region of the sample surfaces in a zone of $5 \mathrm{~mm}$ radius surrounding the centre of each circle on sample surface. A distance of $4 \mathrm{~s}$ was allowed from any probe tip to the nearest edge (where $s$ refers to inter-probe spacing). First to ensure current flow (from constant current source, dc) between two outer probes in $\mathrm{mA}$ range, press contact was made on sample surface. It was ensured that current value did not change by polarity reversal by reversing polarity of connection from the constant current source tapped from a Keithley multimeter
6221. Potential differences between the two inner probes were determined and from the formula $\rho=2 \pi \mathrm{s}(V / I)$, resistivity/conductivity was determined (where $V$ refers voltage between two inner probes and $/$ refers for current passed between two outer probes). The electrical conductivity of samples was determined as follows: multimeter used: Keithley 6221 (containing constant current source and high-input impedance voltmeter); measurement rangecurrent $1 \mu \mathrm{A}-100 \mathrm{~mA}$, voltage $1 \mathrm{nV}-100 \mathrm{~V}$.

\section{Results and discussion}

\subsection{XRD study}

The X-ray diffraction was carried out to investigate crystalline nature, phase purity and interlayer spacing of typical steel coated with a- $\mathrm{Al}_{2} \mathrm{O}_{3}$ and typical a- $\mathrm{Al}_{2} \mathrm{O}_{3}$-graphene (4 wt\%) composite samples. The results obtained are presented in Fig. 1. The samples having phases and planes are identified by comparing the determined $d$-values (experimentally determined) with the $d$-values of standard powder diffraction data file, $\mathrm{C}$ (graphite-2H): 00-0411487 and $\mathrm{a}-\mathrm{Al}_{2} \mathrm{O}_{3}: 01-075-1862$ supplied in JCPDS-ICDD PDF-2 (2004). The XRD results show patterns in $2 \theta$ range of $5^{\circ}-80^{\circ}$. The coating formation and microstructural nature of the samples are confirmed from the XRD analysis. The XRD analysis (Fig. 1a) of $\mathrm{a}-\mathrm{Al}_{2} \mathrm{O}_{3}$ coated on steel shows only peaks of $\mathrm{a}-\mathrm{Al}_{2} \mathrm{O}_{3}$ having different crystal orientations. XRD analysis confirms the presence of only $a-\mathrm{Al}_{2} \mathrm{O}_{3}$ on the substrate of sample. $\alpha-\mathrm{Al}_{2} \mathrm{O}_{3}$ phase shows diffraction peaks of (104), (110), (113), (024), (116), (122) and (214). a- $-\mathrm{Al}_{2} \mathrm{O}_{3}$ shows two major peaks at around $2 \theta=41.2^{\circ}$ and $2 \theta=51.3^{\circ}$. Similar kind of result was reported elsewhere [27]. Figure $1 \mathrm{~b}$ represents the coating of $\mathrm{a}-\mathrm{Al}_{2} \mathrm{O}_{3}$-graphene (4 wt\%) on steel substrate. In the XRD spectra, along the peaks of a- $\mathrm{Al}_{2} \mathrm{O}_{3}$, additional peak of $\mathrm{C}(002)$ is detected. The characteristic peak of $C(002)$ that strongly appeared at around $2 \theta=30.0^{\circ}$ is attributed to the presence of graphene in the $\mathrm{a}-\mathrm{Al}_{2} \mathrm{O}_{3}-$ graphene composite on the surface of steel. C (001) and C (002) were present both in powder and coating of $\mathrm{a}-\mathrm{Al}_{2} \mathrm{O}_{3}$-graphene (4 wt\%). The $\mathrm{C}(001)$ peak with $d$ spacing $0.7 \mathrm{~nm}$ indicates intercalation of oxygen or oxygenated functional groups between layers of graphene forming graphene oxide. $\mathrm{C}(002)$ peak refers to the presence of pure graphene.

The graphene-added $a-\mathrm{Al}_{2} \mathrm{O}_{3}$-graphene composite shows sharper peaks with relatively reduced broadening of peaks. The relative narrow peaks observed for coating $\mathrm{a}-\mathrm{Al}_{2} \mathrm{O}_{3}$-graphene (4 wt\%) in comparison with the coating with pure $\mathrm{a}-\mathrm{Al}_{2} \mathrm{O}_{3}$ can be due to both the presence of microstresses and a change in the grain size. No unwanted impurities were observed in the samples from the XRD 
Fig. 1 a and $\mathbf{b}$ XRD spectra of a- $-\mathrm{Al}_{2} \mathrm{O}_{3}$ and $\mathrm{a}-\mathrm{Al}_{2} \mathrm{O}_{3}$-graphene (4 wt\%)-coated steel substrates, respectively a-alumina coated on steel

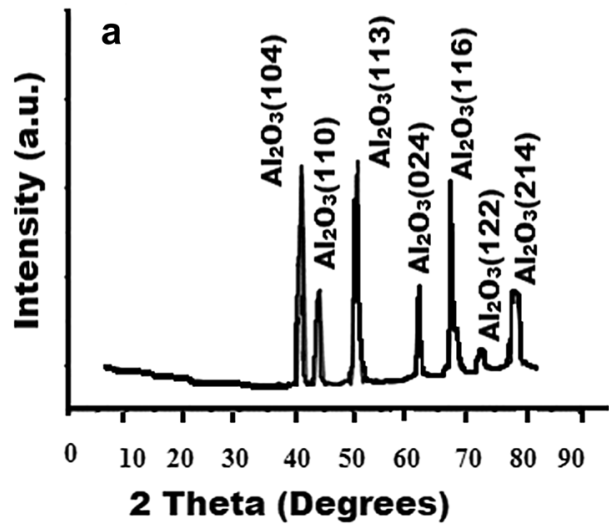

a-alumina-graphene (4 wt\%) coated on steel

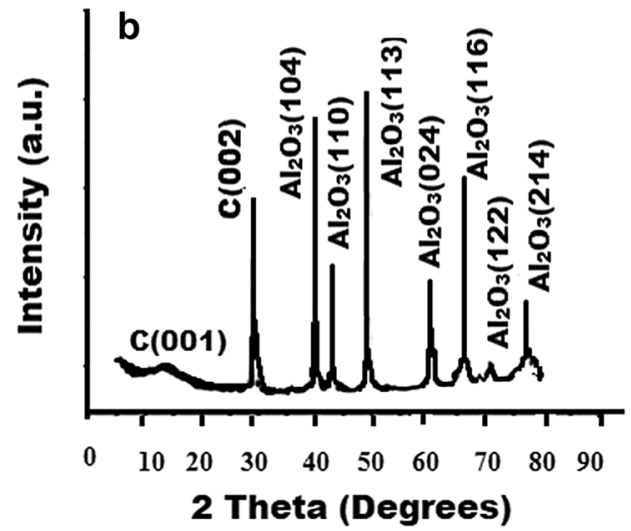

analysis. The absence of Fe peak in the spectra indicates the quality deposition of $\mathrm{a}-\mathrm{Al}_{2} \mathrm{O}_{3}$ and $\mathrm{a}-\mathrm{Al}_{2} \mathrm{O}_{3}$-graphene composite on steel substrate. The position, sharpness and FWHM of the peaks of the different phases were compared to their standard values which indicate the well-ordered and better crystalline nature of the coating formation over steel substrate.

\subsection{Micro-Raman study}

Micro-Raman spectroscopy was used to study the structure, defect levels formed and crystalline behaviour of the ball-milled ( $12 \mathrm{~h}$ ) high-purity graphite, $\mathrm{a}-\mathrm{Al}_{2} \mathrm{O}_{3}$-graphene (4 wt\%) composite powder and $\mathrm{a}-\mathrm{Al}_{2} \mathrm{O}_{3}$-graphene (4 wt\%) composite-coated steel substrate presented in Figs. 2, 3 and 4, respectively. Micro-Raman spectra of high-purity ball-milled samples show peaks corresponding to carbon i.e. D, G and 2D at 1350, 1582 and $2722 \mathrm{~cm}^{1}$, respectively. The $G$ peak is due to the first-order scattering of the $E^{2} g$ phonon from $\mathrm{sp}^{2}$ carbon (graphite lattice) and $D\left(1^{\text {st }}\right.$ order-disorder peak) associates with the strong stacking order of the graphite along the c-axis $[12,28]$. The important fact noticed from Raman analysis that the $2 \mathrm{D}$ (2nd order-disorder peak $[12,28]$ ) peak is not up-shifting, which is an indication of proper Bernal stacking of the graphene layers present in the ball-milled composite samples. D peak represents $1^{\text {st }}$ order-disorder peak in graphene formed due to mechanical ball milling. From micro-Raman spectra it is observed that intensity ratio of $2 D$ to $G$ is around 1. This confirms the presence of graphene as bi-layer in composite. Similar type of bi-layer graphene was reported in our earlier work produced by plasma treatment of graphite [29]. The micro-Raman spectra further confirm the high purity of graphene without any impurities.

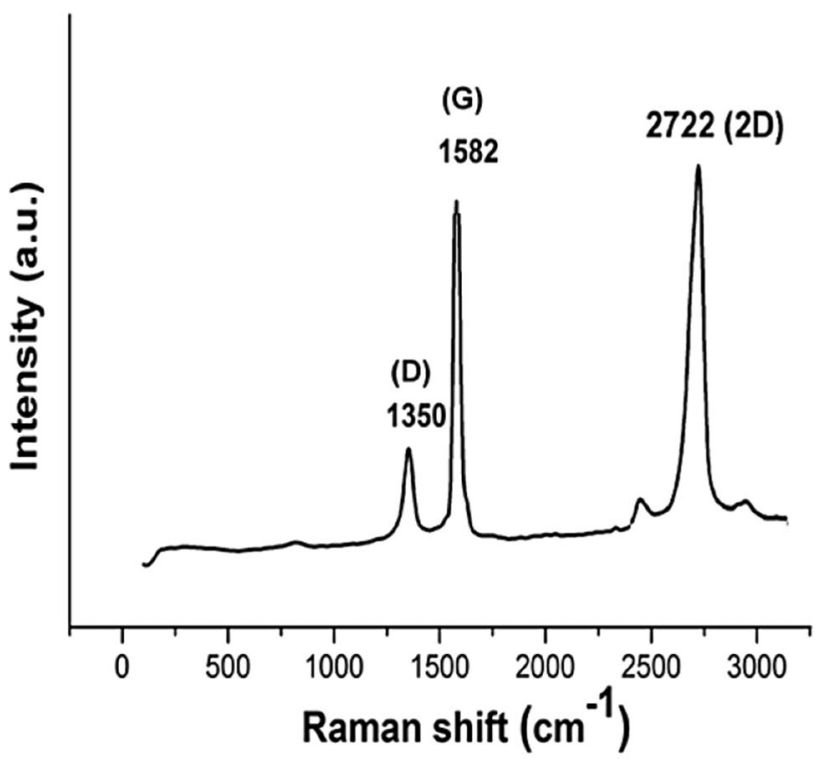

Fig. 2 Micro-Raman spectra of 12-h ball-milled high-purity graphite

Micro-Raman spectra of $a-\mathrm{Al}_{2} \mathrm{O}_{3}$-graphene (4 wt\%) composite powder and coating of a- $\mathrm{Al}_{2} \mathrm{O}_{3}$-graphene composite ( $4 \mathrm{wt} \%$ ) on steel substrate are presented in Figs. 3 and 4 , respectively, which confirm the presence of $\mathrm{a}-\mathrm{Al}_{2} \mathrm{O}_{3}$ and graphene before and after coating on steel surface. $\mathrm{a}-\mathrm{Al}_{2} \mathrm{O}_{3}$-graphene composite shows similar kind of Raman spectra in both cases of before coating (in powder form) and after coating on steel substrate. Peaks of $\mathrm{a}-\mathrm{Al}_{2} \mathrm{O}_{3}, \mathrm{G}$, $\mathrm{D}$ and 2D are observed in the Raman spectra. In Figs. 3 and 4, micro-Raman spectra show D, G and 2D bands at 1346-1348, 1580-1584 and 2702-2704 cm ${ }^{-1}$, respectively. From Fig. 2-4, it clear that graphene retains its structural quality before and after coating. The micro-Raman results can be corroborated to XRD results which confirm 


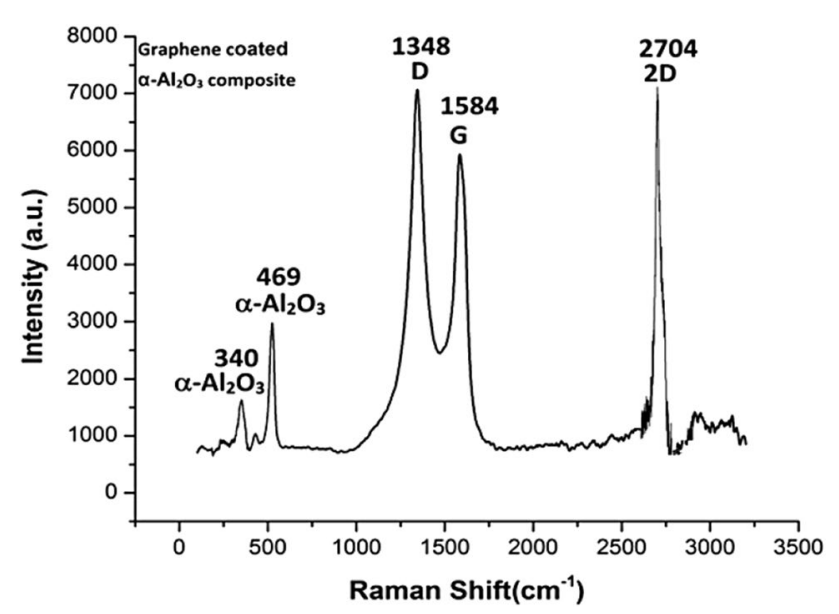

Fig. 3 Micro-Raman spectra of $\mathrm{a}-\mathrm{Al}_{2} \mathrm{O}_{3}$-graphene (4 wt\%) composite powder

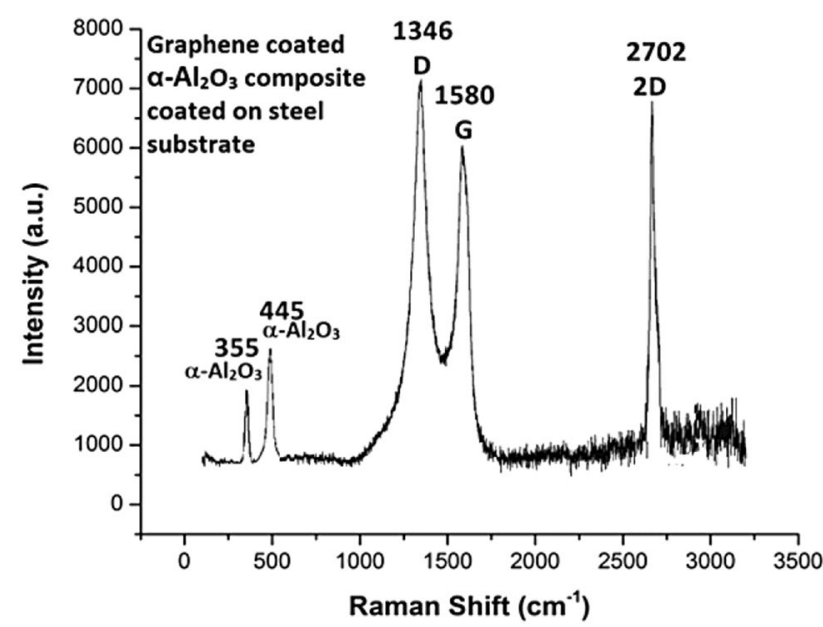

Fig. 4 Micro-Raman spectra of $\mathrm{a}-\mathrm{Al}_{2} \mathrm{O}_{3}$-graphene (4 wt\%) composite-coated steel substrate

successfully formation of typical coatings of $\mathrm{a}-\mathrm{Al}_{2} \mathrm{O}_{3}$ and $\mathrm{a}-\mathrm{Al}_{2} \mathrm{O}_{3}$-graphene on steel substrate.

The intensity ratio of $D$ and $G$ bands $\left(I_{D} / I_{G}\right)$ was used to determine defects and structural changes of graphene material. The intensity ratios of $D$ to $G$ peak i.e. $I_{D} / I_{G}$ for samples was calculated from Figs. 2-4 and presented in Table 1. The significant increase of $D$ peak intensity for a- $\mathrm{Al}_{2} \mathrm{O}_{3}$-graphene (4 wt\%) composite sample in comparison to 12-h ball-milled high-purity graphite sample shows a higher $I_{D} / I_{G}$ (around 1.20) value which indicates structural distortion (oxidation of graphite introduces structural imperfections/disorder created by the hydroxyl, carboxyl and epoxide groups at the basal plane and also at the edges) and size reduction of the in-plane $\mathrm{sp}^{2}$ domain (diminishing of randomly located crystallite size). The result can also be attributed to the formation of bonds (covalent or chemical) between carbon atoms in graphene and oxygen atoms on the surface of corundum particles.

The result was also supported by the presence of $C$ (001) peak for graphene oxide in the $a-\mathrm{Al}_{2} \mathrm{O}_{3}$-graphene (4 $\mathrm{wt} \%$ ) composite sample. The increased $\mathrm{I}_{\mathrm{D}} / \mathrm{I}_{\mathrm{G}}$ ratio indicates the change in electronic conjugation state in the samples but increase of $I_{D} / I_{G}$ ratio can be attributed to decrease of average size of $\mathrm{sp}^{2}$ domains. Therefore, it may be possible that more defect-free $\mathrm{sp}^{2}$ carbons form smaller domains in $\mathrm{a}-\mathrm{Al}_{2} \mathrm{O}_{3}$-graphene (4 wt\%) composite samples than those in 12-h ball-milled high-purity graphite sample, which leads to larger quantities of structural defects. Another possible reason is the increased fraction of graphene edges, which could also contribute to the increase in the $I_{D} / I_{G}$ ratio.

The average crystallite size of the $\mathrm{sp}^{2}$ domains $\left(L_{\mathrm{a}}(\mathrm{nm})\right)$ was calculated for 12-h ball-milled high-purity graphite and $\mathrm{a}-\mathrm{Al}_{2} \mathrm{O}_{3}$-graphene (4 wt\%) composite samples by following the Eq. 1 [12] by relating the $I_{D} / I_{G}$ ratio to the fourth power of laser line wavelength ( $\lambda_{1}$ in $\mathrm{nm}$ units). This equation can be written as

$L_{\mathrm{a}}(\mathrm{nm})=\left(2.4 \times 10^{-10}\right) \lambda_{\mathrm{I}}^{4}\left(I_{\mathrm{D}} / I_{\mathrm{G}}\right)^{-1}$

The calculated $L_{\mathrm{a}}(\mathrm{nm})$ values for $12-\mathrm{h}$ ball-milled high-purity graphite, $\mathrm{a}-\mathrm{Al}_{2} \mathrm{O}_{3}$-graphene (4t\%) composite powder and $\mathrm{a}-\mathrm{Al}_{2} \mathrm{O}_{3}$-graphene (4 wt\%) composite coated on steel are $48.8 \mathrm{~nm}, 14.6 \mathrm{~nm}$ and 14.8 , respectively. Thus, it is observed that the average crystallite size of a- $\mathrm{Al}_{2} \mathrm{O}_{3}$-graphene (4 wt\%) composite decreases which associates with the breaking of crystallites and resulting in the formation of defects, disorders, $\mathrm{sp}^{3}$ hybridization and changes in crystalline.
Table 1 Calculation of $I_{D} / I_{G}$ ratio values from micro-Raman spectra

\begin{tabular}{|c|c|c|c|c|}
\hline Sample ID & D peak, $\left(\mathrm{cm}^{-1}\right)$ & $\mathrm{G}$ peak $\left(\mathrm{cm}^{-1}\right)$ & 2D peak $\left(\mathrm{cm}^{-1}\right)$ & $I_{\mathrm{D}} / I_{\mathrm{G}}$ \\
\hline 12-h ball-milled high-purity graphite & 1350 & 1582 & 2722 & 0.35 \\
\hline $\mathrm{a}-\mathrm{Al}_{2} \mathrm{O}_{3}$-graphene (4 wt\%) composite powder & 1348 & 1584 & 2704 & 1.25 \\
\hline $\begin{array}{l}\mathrm{a}-\mathrm{Al}_{2} \mathrm{O}_{3} \text {-graphene ( } 4 \mathrm{wt} \% \text { ) composite-coated } \\
\text { steel substrate }\end{array}$ & 1346 & 1580 & 2702 & 1.20 \\
\hline
\end{tabular}




\subsection{Microstructural analysis by FESEM}

FESEM and EDS analysis taken on flat top surface of the typical coating of $\mathrm{a}-\mathrm{Al}_{2} \mathrm{O}_{3}$ with $4 \mathrm{wt} \%$ graphene are presented in Fig. 5. FESEM shows two phases of colour contrast such as grey and black. EDS taken on grey phase marked rectangular 1 in FESEM shows major peak of $\mathrm{Al}$ along with minor peaks for $\mathrm{O}$ and $\mathrm{C}$ (Fig. 5b), whereas EDS taken on black phase marked rectangular 2 shows major peak of $\mathrm{C}$ along with minor peak for $\mathrm{O}$ (Fig. $5 \mathrm{C}$ ). From the above results, it may be predicated that $\mathrm{Al}_{2} \mathrm{O}_{3}$ and graphene are the major constituents of grey and black phases, respectively. In FESEM image, almost uniform distribution of $\mathrm{a}-\mathrm{Al}_{2} \mathrm{O}_{3}$-graphene coating was found to grow on steel substrate. No significant pores are marked on the top surface.
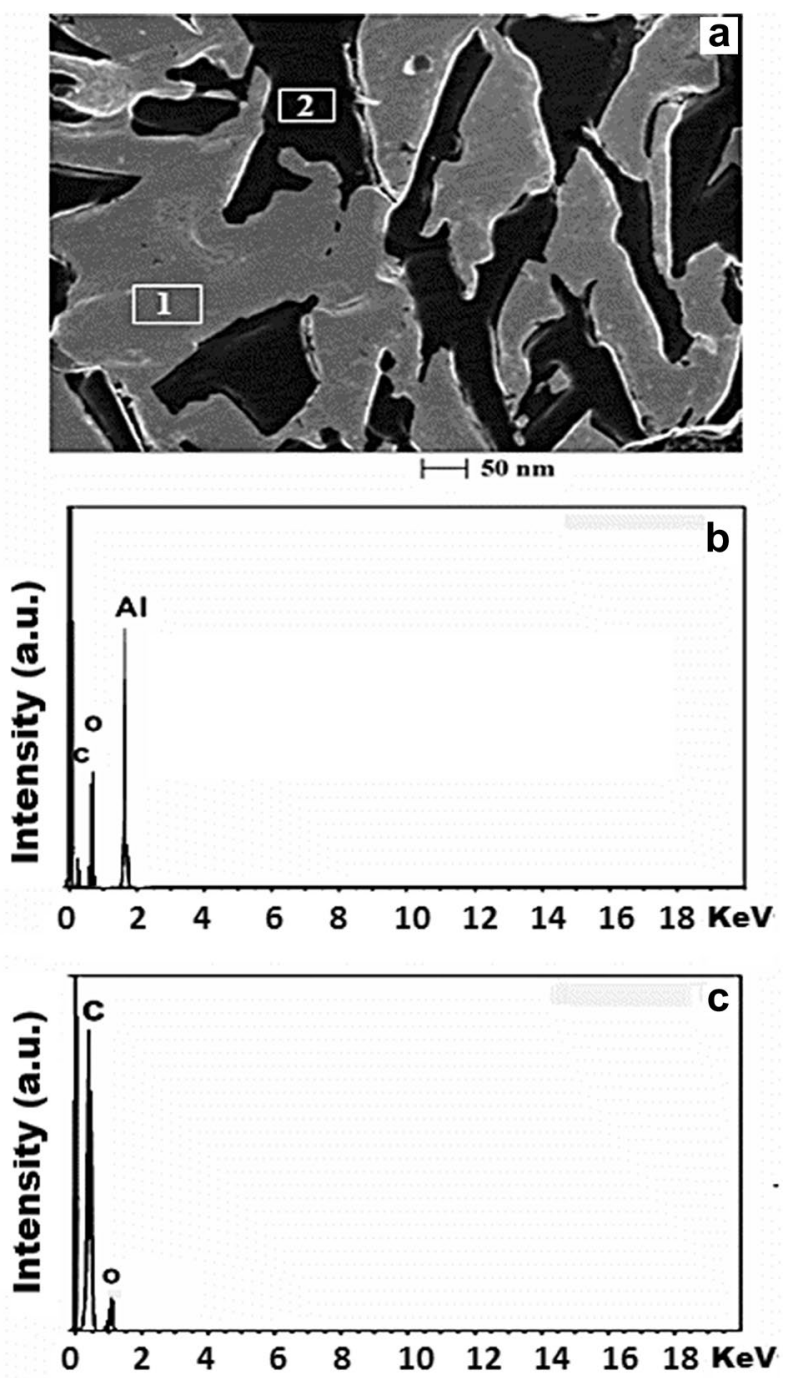

Fig. 5 FESEM and EDS analysis of $a-\mathrm{Al}_{2} \mathrm{O}_{3}-4 \mathrm{wt} \%$ graphene-coated steel substrate: a FESEM image on top surface of coating, $\mathbf{b}$ EDS on marked phase 1, c EDS on marked phase 2
The cross-sectional FESEM image was taken to analyse the change in morphology and thickness of coating. The estimated thickness of the as-synthesized coating is almost nearly $50 \pm 10 \mu \mathrm{m}$ (Fig. 6a). In the cross-sectional view substrate, bond coat layer, top coat (coating) and the resin-mounted layer were clearly observed. No significant pores were detected in the coating except few dark contrast pointed regions which may be due to pores in the sample (marked in red circle). Further, the energy dispersive X-Ray spectroscopic (EDS) elemental line scan was obtained across the coating towards the substrate confirming the elemental distribution of the $\mathrm{Al}, \mathrm{C}$ and $\mathrm{O}$ (Fig. 6b). This high-resolution elemental spectrum (Fig. 6b) confirms the almost uniform distribution of the above three elements across the coating. Additionally, the elemental confirmation and presence of foreign impurities were analysed by EDS. EDS result indicated the presence of foreign impurities like $\mathrm{Fe}, \mathrm{Ni}, \mathrm{Cr}$ and $\mathrm{Au}$. The elements like $\mathrm{Fe}, \mathrm{Ni}$ and $\mathrm{Cr}$ are expected from the steel substrate, whereas Au from the gold conducting coating. FESEM and EDS results can be corroborated to the XRD result showing the presence of reflections of $C(001)$ and $C(002)$ on the $\mathrm{X}$-ray spectrum of the composite which also indicates a predominant orientation of graphene parallel to the coating plane.

\subsection{Mechanical and electrical conductivity studies}

Microhardness and anti-corrosion of $\mathrm{a}-\mathrm{Al}_{2} \mathrm{O}_{3}$ and $\mathrm{a}-\mathrm{Al}_{2} \mathrm{O}_{3}$-graphene composite-coated steel substrates were determined by nanoindentation method and potentiodymanic test (Gamry equipment) and are presented in Figs. 7 and 8, respectively. On the surface of the material, more than 10 indentations were taken and the average of microhardness values of materials are reported in this work. The microhardness of bare steel was determined to be $172 \pm 10 \mathrm{VHN}$ without changing the mechanical strength of bulk steel. Before $\mathrm{a}-\mathrm{Al}_{2} \mathrm{O}_{3}$ and $\mathrm{a}-\mathrm{Al}_{2} \mathrm{O}_{3}-$ graphene coating to steel, it was thought that the coating of such materials may increase the mechanical property of the steel. The results obtained interestingly match to our expectation that after $\mathrm{a}-\mathrm{Al}_{2} \mathrm{O}_{3}$ and $\mathrm{a}-\mathrm{Al}_{2} \mathrm{O}_{3}$-graphene (1, 2 and $4 \mathrm{wt} \%)$ coated on steel, microhardness of steel significantly improved. In this work, $\mathrm{a}-\mathrm{Al}_{2} \mathrm{O}_{3}$-graphene (4 $w t \%)$ composition coated on steel shows higher hardness and Young's modulus of $370 \pm 11$ VHN and $292 \pm 22 \mathrm{GPa}$, respectively. The enhanced surface hardness properties of steel coated with $\mathrm{Al}_{2} \mathrm{O}_{3}$-graphene composite may be attributed to the presence and well dispersion of graphene in the composite. This coating not only enhances the surface hardness value but also improves corrosion resistance by shifting the current density toward much lower value $\left(10^{-9} \mathrm{~A} / \mathrm{cm}^{2}\right)$ from the value of $10^{-6} \mathrm{~A} / \mathrm{cm}^{2}$ (steel). 

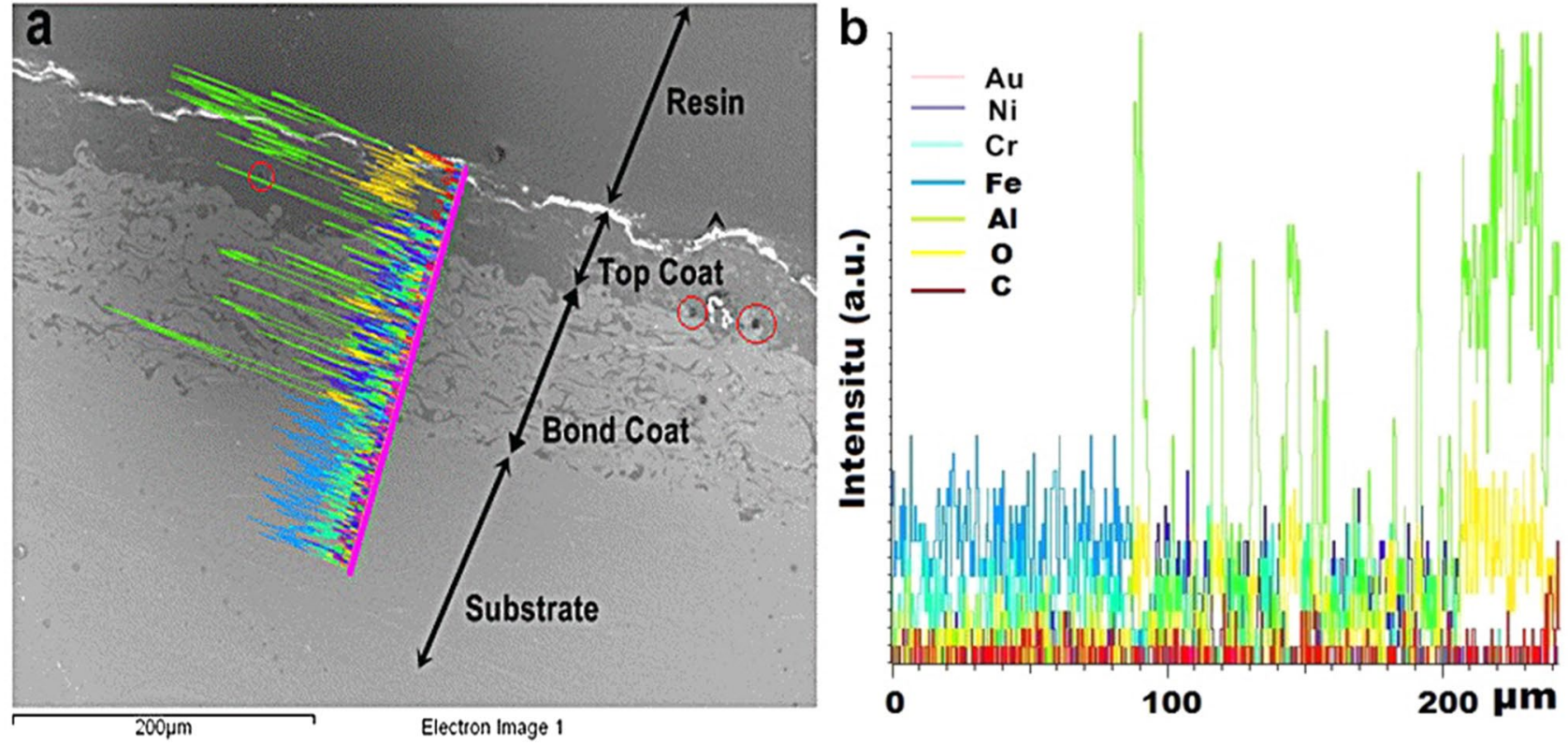

Fig. 6 a Cross-sectional FESEM image of coating of $\mathbf{a}-\mathrm{Al}_{2} \mathrm{O}_{3}-4$ wt\% graphene on steel substrate, $\mathbf{b}$ high-resolution EDS elemental spectra taken on (a)

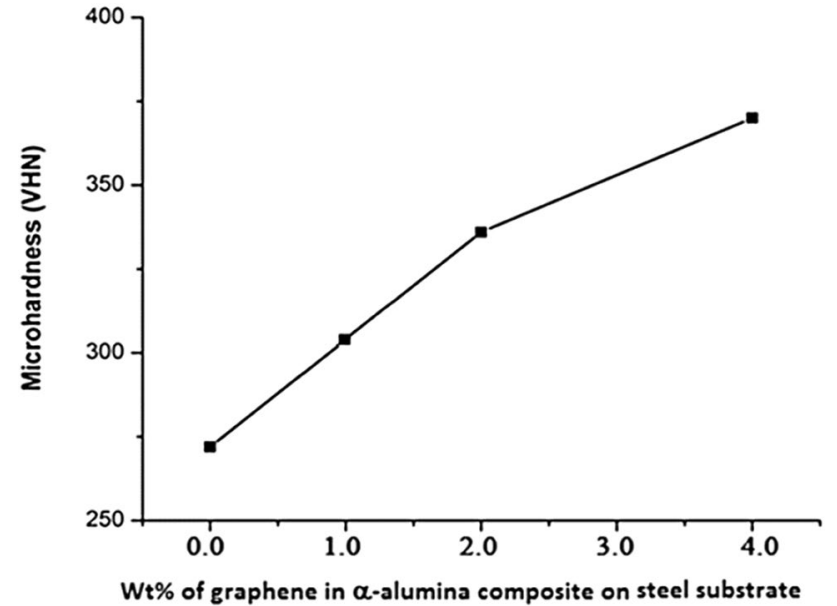

Fig. 7 Microhardness measurement of steel after coating of $\mathrm{a}-\mathrm{Al}_{2} \mathrm{O}_{3}$ and $\mathrm{a}-\mathrm{Al}_{2} \mathrm{O}_{3}-$ graphene $(1,2$ and $4 \mathrm{wt} \%)$

Porosity-free nature of the coating along with optimized adhesion over substrate has some contribution for the development of mechanical property. The above improved microhardness of material inspires to use the product for advanced structural applications in aerospace and automotive industries, etc.

The electrical conductivity determined by four-point probe technique for $\mathrm{a}-\mathrm{Al}_{2} \mathrm{O}_{3}$ and typical $\mathrm{a}-\mathrm{Al}_{2} \mathrm{O}_{3}$-graphene (4 wt\%) composite coated on steel substrate were determined and compared with bare steel substrate. From the

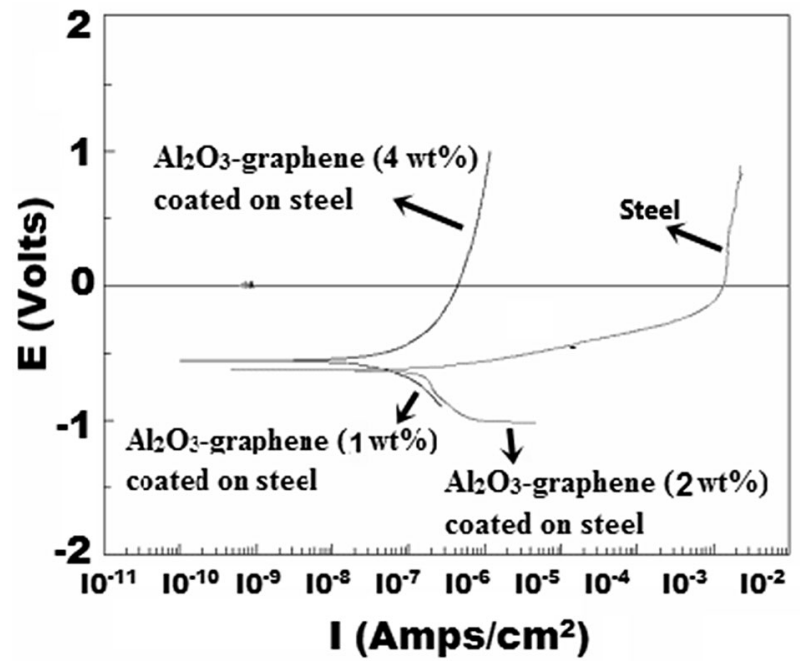

Fig. 8 Potentio-dynamic measurement studies of coated steel

measured values of conductivity, it is found that electrical conductivity of steel was found to be $\sim 5.5 \times 10^{6} \mathrm{~S} / \mathrm{m}$, while the corresponding conductivity value for $\mathrm{a}-\mathrm{Al}_{2} \mathrm{O}_{3}$ and $\mathrm{a}-\mathrm{Al}_{2} \mathrm{O}_{3}$-graphene (4t\%) composite coated on steel was $\sim 1.5 \times 10^{6} \mathrm{~S} / \mathrm{m}$ and $\sim 6.6 \times 10^{6} \mathrm{~S} / \mathrm{m}$, respectively. The improvement of electrical conductivity in case of $\mathrm{a}-\mathrm{Al}_{2} \mathrm{O}_{3}$-graphene (4 wt\%) composite coated on steel is attributed to the presence of high-purity graphene in the composite with well dispersion. 


\section{Conclusion}

We could prepare a coating of $\mathrm{a}-\mathrm{Al}_{2} \mathrm{O}_{3}$ and $\mathrm{a}-\mathrm{Al}_{2} \mathrm{O}_{3}$-graphene composite on steel substrate. After successful $12 \mathrm{~h}$ of ball milling, the composite samples were coated on steel substrate by employing a non-transferred plasma torch technique. XRD analysis confirms coating of $a-\mathrm{Al}_{2} \mathrm{O}_{3}$ and $\mathrm{a}-\mathrm{Al}_{2} \mathrm{O}_{3}$-graphene composite on steel substrate. Micro-Raman spectra of ball-milled high-purity graphene show peaks of $D, G$ and $2 D$. The ratio of intensity of $2 D$ to $G$ was found to be nearly one which confirms bi-layer form of graphene. Micro-Raman spectra confirm the presence of $\mathrm{a}-\mathrm{Al}_{2} \mathrm{O}_{3}-$ graphene composite, before and after coating on steel surface. The formation of coating and its microstructure was observed by FESEM analysis. Almost uniform distribution of coating of $\mathrm{a}-\mathrm{Al}_{2} \mathrm{O}_{3}$-graphene (4 $w t \%)$ composite on steel substrate was found in the sample. In this work, $\mathrm{a}-\mathrm{Al}_{2} \mathrm{O}_{3}$-graphene (4 wt\%) composite coated on steel shows higher hardness values of $370 \pm 11$ VHN. a- $\mathrm{Al}_{2} \mathrm{O}_{3}$-graphene (4 wt\%) composite-coated steel was found to exhibit significant electrical conductivity of $\sim 6.6 \times 10^{6} \mathrm{~S} / \mathrm{m}$. The above coating with improved mechanical and electrical properties has great potential for advanced electronic, ceramic and structural applications. More research is to be carried out to further discover processing conditions that advance these goals.

Acknowledgements We acknowledge our team mates and scientist who have been helping throughout the work at IMMT, Bhubaneswar.

\section{Compliance with ethical standards}

Conflict of interest On behalf of all authors, the corresponding author states that there is no conflict of interest.

\section{References}

1. Singh TB, Singh MN, Basu DK, Narang SK (2003) Corrosion behaviour of electro deposited zinc-iron alloy coatings on mild steel. J of Met and Mat Sci 45:199-203

2. Yanjerappa AN, Thimmappa VV, Perdur VN (2002) Electrodeposition of Zinc from chloride solution. Turk J Chem 26:725-734

3. Thangaraj V, Eliaz N, Chitharanjan A (2009) Corrosion behavior of composition modulated multilayer $\mathrm{Zn}$-Co electrodeposits produced using a single-bath technique. J of Appl Electrochem 39:339

4. Yogesha S, Hegde AC (2011) Optimization of deposition conditions for development of high corrosion resistant $\mathrm{Zn}-\mathrm{Fe}$ multilayer coatings. J Mater Process Technol 211:1409-1415

5. Shivakumara S, Manohar U, Naik YA, Venkatesha TV (2007) Influence of additives on electrodeposition of bright $\mathrm{Zn}-\mathrm{Ni}$ alloy on mild steel from acid sulphate bath. Bull Mat Sci 30:455-462

6. Daniyan AA, Umoru LE, Popoola P, Fayomi OSIF (2017) Comparative studies of microstructural, tribological and corrosion properties of $\mathrm{Zn}-\mathrm{TiO}_{2}$ and $\mathrm{Zn}-\mathrm{TiO}_{2}-\mathrm{WO}_{3}$ nano-composite coatings. Result Phys 7:3222-3229

7. Pedroza GAG, De Souza CAC, Carlos IA, Lima LRPA (2012) Evaluation of the effect of deposition bath glycerol content on zinc-nickel electrodeposits on carbon steel. Surf Coat Tech 206:2927-2932

8. Chen WX, Tu JP, Wang LY, Gan HY, Xu ZD, Zhang XB (2003) Tribological application of carbon nanotubes in a metal-based composite coating and composites. Carbon 41:215-222

9. Balani B, Harimkar SP, Keshri A, Chen Y, Dahotre NB, Agarwal A (2008) Multiscale wear of plasma-sprayed carbon-nanotubereinforced aluminum oxide nanocomposite coating. Acta Mater 56:5984-5994

10. Keshri AK, Agarwal A (2012) Wear behavior of plasma-sprayed carbon nanotube-reinforced aluminum oxide coating in marine and high-temperature environments. J Therm Spray Technol 20:1217-1230

11. Geim AK, Novoselov KS (2007) The rise of graphene. Nat Mater 6:183-191

12. Dash P, Dash T, Rout TK, Sahu AK, Das S, Biswal SK, Mishra BK (2016) Preparation of graphene oxide by dry planetary ball milling process from natural graphite. RSC Adv 6:12657-12668

13. Gunasekaran RK, Jayasankar K, Dash T, Dash A, Jena BK, Mishra BK (2016) Shear-force-dominated dual-drive planetary ball milling for scalable production of graphene and its electrocatalytic application with Pd nanostructures. RSC Adv V 6(24):20067-20073

14. Zhu BY, Murali S, Cai W et al (2010) Graphene and graphene oxide: synthesis, properties and applications. Adv Mater 22:3906-3924

15. Allen MJ, Tung VC, Kaner RB (2010) Honeycomb carbon: a review of graphene. Chem Rev 110:132-145

16. Wang J, Ma F, Sun M (2007) Graphene, hexagonal boron nitride, and their heterostructures: properties and applications. RSC Adv 7:16801-16822

17. Sun Y, Wu Q, Shi G (2011) Graphene based new energy materials Energ. Environ Sci 4:1113-1132

18. Ovidko IA (2014) Metal-Graphene nanocomposites with enhanced mechanical properties: A review. reviews on advanced materials Science. Rev Adv Mat Sci 38:190-200

19. Al-Sammarraie AMA, Raheema MH (2017) Electrodeposited reduced graphene oxide films on stainless steel, copper, and aluminum for corrosion protection enhancement. Inter J Corros 2017:1-8

20. Dennis RV, Viyannalage LT, Gaikwad AV, Rout TK, Banerjee S (2013) Graphene nanocomposite coatings for protecting lowalloy steels from corrosion. Am Ceram Soc Bull 92(5):18-24

21. Yina H, Daia Q, Haob X, Huanga W, Wanga X (2018) Preparation and tribological properties of graphene oxide doped alumina composite coatings. Surf Coat Tech 352:411-419

22. Fan $Y$, Jiang W, Kawasaki A (2012) Highly conductive few-layer graphene $/ \mathrm{Al}_{2} \mathrm{O}_{3}$ nanocomposites with tunable charge carrier type. Adv Funct Mater 22:3882

23. Hentour K, Marsal A, Turq V, Weibel A, Ansart F, Sobrino JM, Chen YM, Garcia J, Franc P, Cardey O, Laurent C (2016) Carbon nanotube/alumina and graphite/alumina composite coatings on stainless steel for tribological applications. Mater Today 8:118-126

24. Ahmad I, Cao HZ, Chen HH, Zhao H, Kennedy A, Zhu YQ (2010) Carbon toughened aluminium oxide nanocomposite. J Eur Ceram Soc 30:865-873

25. Choudhary RK, Kain V, Hubli RC (2014) Formation of alumina aluminide coatings on ferritic-martensitic T91 steel. J Min Metall Sect B-Metall 50:165-170

26. Stolyarov VV, Misochenko AA, Zholnin AG, Grigiriev EG, Klyatskina EA (2017) Structure and properties of $\mathrm{Al}_{2} \mathrm{O}_{3} /$ Graphene 
nanocomposite processed by spark plasma sintering. IOP Conf Series Mater Sci Eng 218:1-4

27. Gheorghies $C$, Condurache-bota S, Dinescu M, Constantinescu C, Cazacu N (2008) New reinforcing technique of alumina coatings on steel substrates. Optoelectron Adv Mat 2:569-577

28. Yazdani B, Xu F, Ahmad I, Hou X, Xia Y, Zhu Y (2015) Tribological performance of Graphene/Carbon nanotube hybrid reinforced $\mathrm{Al}_{2} \mathrm{O}_{3}$ composites. Sci Rep 5:1-11

29. Nayak BB, Sahu RK, Dash T, Pradhan S (2018) Growth of carbon nanotubes in arc plasma treated graphite disc: microstructural characterization and electrical conductivity study. Appl Phys A $124: 1-9$

Publisher's Note Springer Nature remains neutral with regard to jurisdictional claims in published maps and institutional affiliations. 